\title{
PENGARUH KUALITAS PELAYANAN TERHADAP KEPUASAN PELANGGAN PADA RESTORAN DAN PENACINGAN AJO KARAWANG BARAT
}

\author{
Wanta \\ Fakultas Bisnis dan Ilmu Sosial Universitas Buana Perjuangan Karawang \\ email : wanta@ubpkarawang.ac.id ; HP.081286968419
}

\begin{abstract}
ABSTRAK
Penelitian ini dilaksanakan pada pelanggan Restoran dan Pemancingan Ajo Karawang Barat, populasi dalam penelitian ini yaitu seluruh pelanggan Restoran dan Pemancingan Ajo yang datang selama penelitian berlangsung. Penelitian ini bertujuan untuk mengetahui pengaruh kualitas pelayanan terhadap kepuasan pelanggan Restoran dan Pemancingan Ajo - Karawang Barat. Alat analisis yang digunakan yaitu uji validitas, uji reliabilitas, analisis korelasi dan analisis regresi linier sederhana.

Hasil analisis korelasi kualitas pelayanan dengan kepuasan masyarakat diperoleh nilai korelasi sebesar 0,779 . Nilai korelasi tersebut berada pada daerah kuat $(0,600-0,799=$ kuat) dan positif (searah) atau dapat dikatakan bahwa korelasi atau hubungan kualitas pelayanan dengan kepuasan pelanggan mempunyai tingkat hubungan kuat dan searah (positif). Jika kualitas pelayanan naik maka kepuasan pelanggan akan naik, demikian sebaliknya.

Hasil analisis regresi linier model summary diperoleh nilai koefisien korelasi $(\mathrm{R})$ sebesar 0,779 atau $R>0$, artinya bahwa terdapat hubungan kuat $(0,600$ - 0,799 = kuat) antara kualitas pelayanan dengan kepuasan pelanggan. Nilai koefisien determinasi ( $\mathrm{R}$ Square atau $\mathrm{R}^{2}$ ) sebesar 0,60,70 atau $60,70 \%$. Nilai tersebut menunjukan kemampuan variabel kualitas pelayanan $(\mathrm{X})$ menjelaskan variansi pada variabel kepuasan pelanggan (Y) sebesar 60,70\% dan sisanya sebesar $39,30 \%$ dipengaruhi oleh faktor lain (e) yang tidak diikutsertakan dalam penelitian ini. Faktor lain tersebut seperti pemberian kompensasi, budaya organisasi, motivasi kerja, prestasi kerja dan lain-lain. Hasil analisis regresi linier model anova diperoleh nilai signifikansi $\mathrm{F}$ sebesar 0,000 (P-value) artinya bahwa variabel kualitas pelayanan $(\mathrm{X})$ berpengaruh signifikan terhadap variabel kepuasan pelanggan $(\mathrm{Y})$. Atau dengan memperhatikan nilai $F_{\text {hitung }}(344,754)$ yang mempunyai nilai lebih besar dari nilai $F_{\text {tabel }}(3,89)$ atau 344,754 > 3,89 yang berarti bahwa variabel kualitas pelayanan $(\mathrm{X})$ berpengaruh terhadap variabel kepuasan pelanggan (Y). Hasil analisis regresi linear model coefficients diperoleh persamaan regresi linear ganda yaitu $\mathrm{Y}=12,305+0,722 \mathrm{X}+\mathrm{e}$.
\end{abstract}

Kata kunci : Kualitas Pelayanan, Kepuasan Pelanggan 


\section{PENDAHULUAN}

Perkembangan dunia usaha saat ini telah membawa para pelaku ekonomi pada persaingan yang sangat ketat untuk memperebutkan konsumen. Berbagai pendekatan dilakukan untuk mendapatkan simpati konsumen baik melalui peningkatan sarana dan prasarana, berfasilitas teknologi tinggi maupun dengan pengembangan sumber daya manusia. Persaingan untuk memberikan yang terbaik kepada konsumen telah menempatkan konsumen sebagai pengambil keputusan. Semakin banyaknya perusahaan sejenis yang beroperasi dengan berbagai produk / jasa yang ditawarkan, membuat masyarakat dapat menentukan pilihan sesuai dengan kebutuhannya.

Dewasa ini, keberhasilan pemasaran suatu perusahaan tidak hanya dinilai dari seberapa banyak konsumen yang berhasil diperoleh, namun juga bagaimana cara mempertahankan konsumen tersebut. Dalam pemasaran dikenal bahwa setelah konsumen melakukan keputusan pembelian, ada proses yang dinamakan tingkah laku pasca pembelian yang didasarkan pada rasa puas dan tidak puas. Rasa puas dan tidak puas konsumen terletak pada hubungan antara harapan konsumen dengan prestasi yang diterima dari produk atau jasa. Bila produk atau jasa tidak memenuhi harapan konsumen, konsumen merasa tidak puas, sehingga dimasa yang akan datang konsumen tidak akan melakukan pembelian ulang. Di lain pihak apabila sebuah produk atau jasa melebihi harapan konsumen, konsumen akan merasa puas dan akan melakukan pembelian ulang.

Berdasarkan uraian latar belakang permasalahan di atas maka peneliti tertarik ingin melakukan penelitian dengan judul Pengaruh Kualitas Pelayanan terhadap Kepuasan Pelanggan pada Restoran dan Pemancingan Ajo - Karawang Barat.

\section{RUMUSAN MASALAH}

Perumusan masalah yang dapat dirumuskan dalam penelitian ini yaitu :

1. Bagaimanakah tingkat kualitas pelayanan yang ada pada restoran dan pemancingan Ajo - Karawang Barat?

2. Bagaimanakah tingkat kepuasan pelanggan yang ada pada restoran dan pemancingan Ajo - Karawang Barat? 
3. Bagaimana pengaruh kualitas pelayanan terhadap kepuasan pelanggan pada restoran dan pemancingan Ajo - Karawang Barat?

\section{TUJUAN PENELITIAN}

Berdasarkan rumusan masalah di atas, maka tujuan penelitian ini adalah :

1. Untuk mengetahui tingkat kualitas pelayanan yang ada pada restoran dan pemancingan Ajo - Karawang Barat.

2. Untuk mengetahui tingkat kepuasan pelanggan pada restoran dan pemancingan Ajo - Karawang Barat.

3. Untuk mengetahui pengaruh kualitas pelayanan terhadap kepuasan pelanggan pada restoran dan pemancingan Ajo - Karawang Barat.

\section{LANDASAN TEORI}

\section{Kualitas Pelayanan}

Modernitas dengan kemajuan teknologi akan mengakibatkan persaingan yang sangat ketat untuk memperoleh dan mempertahankan pelanggan. Kualitas pelayanan menjadi suatu keharusan yang harus dilakukan perusahaan supaya mampu bertahan dan tetap mendapat kepercayaan pelanggan. Pola konsumsi dan gaya hidup pelanggan menuntut perusahaan mampu memberikan pelayanan yang berkualitas. Keberhasilan perusahaan dalam memberikan pelayanan yang berkualitas dapat ditentukan dengan pendekatan service quality yang telah dikembangkan oleh Parasuraman, Berry dan Zenthaml (dalam Lupiyoadi, 2006).

Service Quality adalah seberapa jauh perbedaan antara harapan dan kenyataan para pelanggan atas layanan yang mereka terima. Service Quality dapat diketahui dengan cara membandingkan persepsi pelanggan atas layanan yang benar-benar mereka terima dengan layanan sesungguhnya yang mereka harapkan. Kualitas pelayanan menjadi hal utama yang diperhatikan serius oleh perusahaan, yang melibatkan seluruh sumber daya yang dimiliki perusahaan.

Terdapat lima dimensi kualitas pelayanan menurut Parasuraman dalam Lupiyoadi (2006), yaitu :

1. Tangibles, atau bukti fisik yaitu kemampuan perusahaan dalam menunjukkan eksistensinya kepada pihak eksternal. Yang dimaksud bahwa penampilan dan 
kemampuan sarana dan prasarana fisik perusahaan dan keadaan lingkungan sekitarnya adalah bukti nyata dan pelayanan yang diberikan.

2. Reliability, atau kehandalan yaitu kemampuan perusahaan untuk memberikan pelayanan sesuai yang dijanjikan secara akurat dan terpercaya.

3. Responsiveness, atau ketanggapan yaitu suatu kemauan untuk membantu dan memberikan pelayanan yang cepat dan tepat kepada pelanggan dengan penyampaian informasi yang jelas.

4. Assurance, atau jaminan dan kepastian yaitu pengetahuan, kesopansantunan, dan kemampuan para pegawai perusahaan untuk menumbuhkan rasa percaya para pelanggan kepada perusahaan. Terdiri dari beberapa komponen antara lain komunikasi, kredibilitas, keamanan, kompetensi dan sopan santun.

5. Empathy, yaitu memberikan perhatian yang tulus dan bersifat individual atau pribadi yang diberikan kepada para pelanggan dengan berupaya memahami keinginan pelanggan. Sebagai contoh perusahaan harus mengetahui keinginan pelanggan secara spesifik dari bentuk fisik produk atau jasa sampai pendistribusian yang tepat.

\section{Kepuasan Pelanggan}

Dewasa ini perhatian terhadap kepuasan maupun ketidakpuasan pelanggan telah semakin besar karena pada dasarnya tujuan dari suatu perusahaan adalah untuk menciptakan rasa puas pada pelanggan. Semakin tinggi tingkat kepuasan pelanggan, maka akan mendatangkan keuntungan yang semakin besar bagi perusahaan, karena pelanggan akan melakukan pembelian ulang terhadap produk perusahaan. Namun, apabila tingkat kepuasan yang dirasakan pelanggan kecil, maka terdapat kemungkinan bahwa pelanggan tersebut akan pindah ke produk pesaing.

Menurut Kotler, kepuasan adalah tingkat perasaan seseorang setelah membandingkan kinerja atau hasil yang dia rasakan dibandingkan dengan harapannya (Kotler dkk, 2000). Sedangkan Tse dan Wilton (1988) dalam Lupiyoadi (2004) kepuasan atau ketidakpuasan pelanggan adalah respon pelanggan terhadap evaluasi ketidaksesuaian (disconfirmation) yang dirasakan antara harapan sebelumnya dan kinerja aktual produk yang dirasakan setelah pemakaiannya. 
Fandy Tjiptono, Gregorius Chandra \& Dadi Adriana (2008), mengatakan sampai saat ini kepuasan pelanggan diinterprestasikan dan diteliti berdasarkan 10 teori yang dapat dikelompokan berdasarkan tiga perspektif utama : prespektif psikologi, prespektif ekonomi, presfektif sosiologi. Seperti yang terlihat di bawah ini :

Gambar 1.2

Sepuluh Teori Pokok Kepuasan Pelanggan

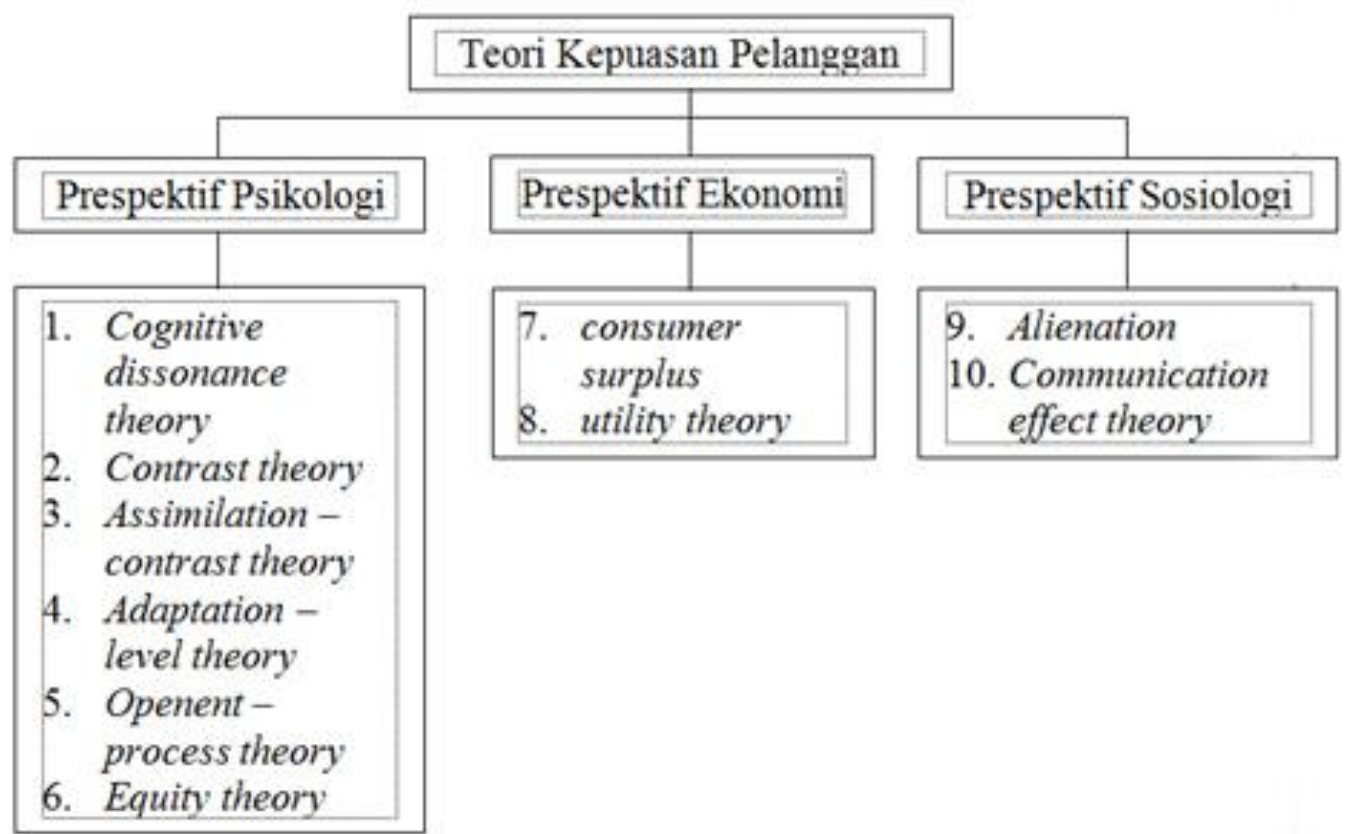

Sumber : Fandy Tjiptono, Gregorius Chandra dan Dadi Adriana (2008)

\section{DESAIN PENELITIAN}

Rancangan atau desain penelitian ini menggunakan uji validitas, uji reliabilitas, analisa statistik deskriptif, analisa korelasi dan analisa regresi linier sederhana. Variabel penelitian terdiri dari dua variabel yaitu variabel bebas (independent variable) dan variabel terikat (dependent variable). Variabel bebasnya yaitu kualitas pelayanan yang selanjutnya diberi kode $\mathrm{X}$ dan variabel terikatnya yaitu kepuasan konsumen yang selanjutnya diberi kode Y. Alat pengumpulan data yang digunakan yaitu riset lapangan dan kuisioner.

\section{METODE ANALISIS DATA}

Analisis data yang digunakan adalah analisis korelasi yaitu untuk mengukur keeratan hubungan linier antara dua variabel. Analisis regresi linier sederhana, analisis ini 
digunakan untuk menguji apakah ada pengaruh antara variabel bebas (kualitas pelayanan) terhadap variabel terikat (kepuasan pelanggan). Analisis regresi linier dalam penelitian ini dengan menggunakan metode regression linear-analysis, hasil analisis dapat dilihat pada out put model summary, model anova dan model coefficients dengan menggunakan software SPSS.

\section{HASIL DAN PEMBAHASAN}

\section{Kualitas Pelayanan}

Uji validitas variabel kualitas pelayanan (X) dilakukan dengan mengkorelasikan skor setiap item pertanyaan dengan total skor seluruh item. Hasil uji validitas dapat dilihat baris jumlah mulai dari P X-01 sampai dengan P X-20. Dari data tersebut diperoleh nilai Sig. (2-tailed / 0,000) lebih kecil dari alpha $(\alpha=$ $5 \%$ atau 0,05$)$ dengan tingkat kepercayaan 95\%. Hal tersebut menunjukan bahwa pertanyaan-pertanyaan yang terdapat pada variabel kualitas pelayanan (X) dinyatakan valid dan dapat digunakan untuk pengolahan data selanjutnya dalam penelitian ini.

Hasil uji reliabilitas variabel kualitas pelayanan $(\mathrm{X})$ dapat dilihat pada kolom cronbach's alpha if item deleted variabel kualitas pelayanan (X) sebesar 0,914 , nilai tersebut lebih besar dari nilai $\mathrm{r}_{\text {tabel }}(0,138 /$ pada lampiran $)$ untuk $\mathrm{df}=$ $225-2=223$ dengan tingkat signifikansi 5\%. Sehinga butir-butir pertanyaan variabel kualitas pelayanan $(\mathrm{X})$ dinyatakan reliabel dan dapat dipergunakan pada instrumen penelitian berikutnya.

\section{Kepuasan Pelanggan}

Uji validitas variabel kepuasan pelanggan (Y) dilakukan dengan mengkorelasikan skor setiap item pertanyaan dengan total skor seluruh item. Hasil uji validitas dapat dilihat baris jumlah mulai dari P Y-01 sampai dengan P Y-20. Dari data tersebut diperoleh nilai Sig. (2-tailed / 0,000) lebih kecil dari alpha $(\alpha=$ $5 \%$ atau 0,05$)$ dengan tingkat kepercayaan $95 \%$. Hal tersebut menunjukan bahwa pertanyaan-pertanyaan yang terdapat pada variabel kepuasan konsumen (Y) dinyatakan valid dan dapat digunakan untuk pengolahan data selanjutnya dalam penelitian ini. 
Hasil uji reliabilitas variabel kepuasan pelanggan (Y) dapat dilihat pada kolom cronbach's alpha if item deleted variabel kepuasan konsumen (Y) sebesar 0,918 , nilai tersebut lebih besar dari nilai $r_{\text {tabel }}(0,135 /$ pada lampiran $)$ untuk $\mathrm{df}=$ $225-2=223$ dengan tingkat signifikansi 5\%. Sehinga butir-butir pertanyaan variabel kepuasan pelanggan (Y) dinyatakan reliabel dan dapat dipergunakan pada instrumen penelitian berikutnya.

\section{Analisis Korelasi}

Hasil analisis korelasi kualitas pelayanan dengan kepuasan pelanggan terlihat pada tabel 1.2 berikut ini :

Tabel 1.1

Analisis Korelasi Kualitas Pelayanan dengan Kepuasan Pelanggan

Correlations

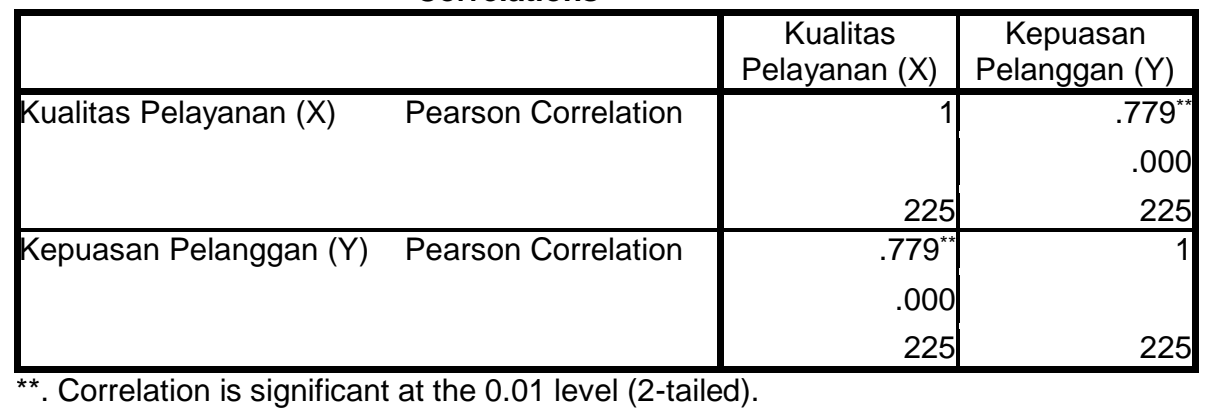

Sumber : Hasil Pengolahan Data Tahun 2018

Berdasarkan data pada tabel tersebut, korelasi kualitas pelayanan dengan kepuasan konsumen yaitu sebesar 0,779 , nilai korelasi tersebut berada pada daerah kuat $(0,600-0,799=$ kuat $)$ dan positif (searah) atau dapat dikatakan bahwa korelasi atau hubungan kualitas pelayanan $(\mathrm{X})$ dengan kepuasan pelanggan (Y) mempunyai tingkat hubungan kuat dan searah (positif). Jika kualitas pelayanan naik maka kepuasan pelanggan akan naik, demikian sebaliknya.

\section{Analisis Regresi}

Hasil analisis regresi linier sederhana mengenai pengaruh kualitas pelayanan terhadap kepuasan pelanggan pada restoran dan pemancingan Ajo Karawang Barat dengan menggunakan model summary, model anova dan model coefficients.

\section{Model Summary}


Hasil analisis regresi linier model summary terlihat pada tabel berikut ini :

Tabel 1.2

Analisis Regresi Linier Model Summary

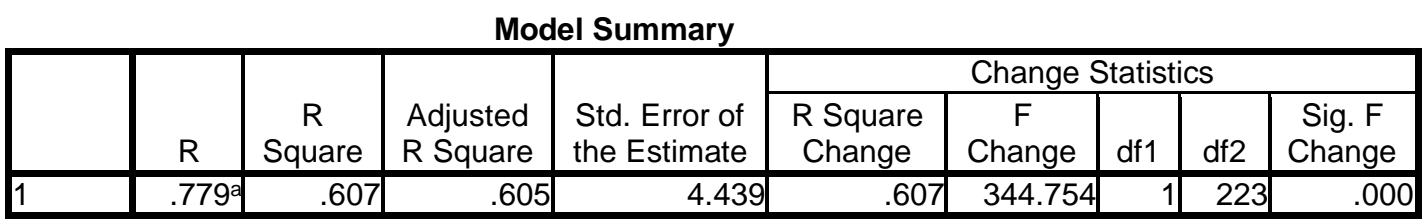

a. Predictors: (Constant), Kualitas Pelayanan $(\mathrm{X})$

Sumber : Hasil Pengolahan Data Tahun 2018

Berdasarkan data pada tabel tersebut diperoleh keluaran nilai koefisien korelasi $(\mathrm{R})$ sebesar 0,779 atau $R>0$, artinya bahwa terdapat hubungan kuat $(0,600$ $-0,799=$ kuat) antara kualitas pelayanan dengan kepuasan pelanggan.

Keluaran nilai koefisien determinasi (R Square atau $\mathrm{R}^{2}$ ) sebesar 0,607 atau 60,70\%. Nilai tersebut menunjukan kemampuan variabel kualitas pelayanan (X) menjelaskan variansi pada variabel kepuasan pelanggan (Y) sebesar $60,70 \%$ dan sisanya sebesar 39,30\% dipengaruhi oleh faktor lain (e) yang tidak diikutsertakan dalam penelitian ini. Faktor lain tersebut seperti pemberian kompensasi, budaya organisasi, kualitas produk, manajemen organisasi dan lain-lain.

\section{Model Annova}

Dalam menjelaskan koefisien F garis regresi pada penelitian ini, nilai alpha ditetapkan sebesar 0,05 atau 5\% $(\alpha=5 \%)$. Keluaran analisis regresi linier model anova terlihat pada tabel 1.3 berikut ini :

Tabel 1.3

Analisis Regresi Linier Model Anova

ANOVA $^{\mathrm{a}}$

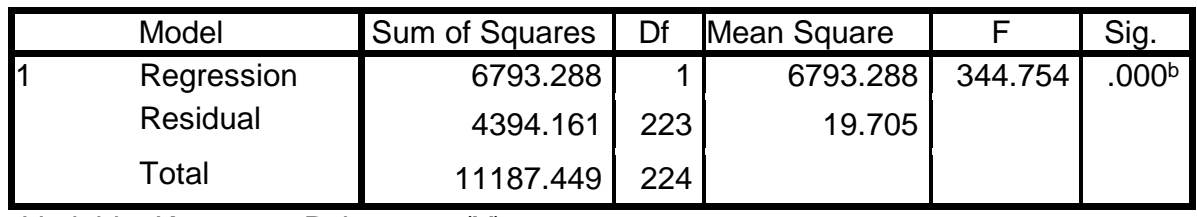

Variable: Kepuasan Pelanggan $(\mathrm{Y})$

(Constant), Kualitas Pelayanan (X)

Sumber : Hasil Pengolahan Data Tahun 2018

Berdasarkan data pada tabel tersebut diperoleh nilai signifikansi $\mathrm{F}$ sebesar 0,000 (P-value) artinya bahwa variabel kualitas pelayanan $(\mathrm{X})$ berpengaruh signifikan terhadap variabel kepuasan pelanggan (Y). Atau dengan memperhatikan 
nilai $F_{\text {hitung }}(344,754)$ yang mempunyai nilai lebih besar dari nilai $F_{\text {tabel }}(3,89)$ atau 344,754 > 3,89 yang berarti bahwa variabel kualitas pelayanan (X) berpengaruh signifikan terhadap variabel kepuasan pelanggan (Y).

\section{Model Coefficients}

Hasil analisis regresi linier model coefficients terlihat pada tabel 1.4 berikut ini :

\section{Tabel 1.4}

Analisis Regresi Linier Model Coefficients

\begin{tabular}{|c|c|c|c|c|c|c|}
\hline \multicolumn{7}{|c|}{ Coefficients $^{a}$} \\
\hline \multirow{2}{*}{\multicolumn{2}{|c|}{ Model }} & \multicolumn{2}{|c|}{$\begin{array}{l}\text { Unstandardized } \\
\text { Coefficients }\end{array}$} & $\begin{array}{c}\text { Standardized } \\
\text { Coefficients }\end{array}$ & \multirow[b]{2}{*}{$\mathrm{t}$} & \multirow[b]{2}{*}{ Sig. } \\
\hline & & $\mathrm{B}$ & Std. Error & Beta & & \\
\hline & (Constant) & 12.305 & 2.700 & & 4.557 & .000 \\
\hline & Kualitas Pelayanan $(\mathrm{X})$ & .722 & .039 & .779 & 18.568 & .000 \\
\hline
\end{tabular}

a. Dependent Variable: Kepuasan Pelanggan (Y)

Sumber : Hasil Pengolahan Data Tahun 2018

Berdasarkan data pada tabel di atas yang digunakan untuk membuat persamaan regresi linear yaitu besaran koefisien yang terdapat pada kolom unstandardized coefficients bagian $\mathrm{B}$, sehingga diperoleh persamaan regresi linear sebagai berikut :

$$
\mathrm{Y}=12,305+0,722 \mathrm{X}+\mathrm{e}
$$

Persamaan regresi linier tersebut dapat dideskripsikan sebagai berikut :

1. Nilai koefisien sebesar 12,305 adalah nilai koefisien kepuasan pelanggan (Y) saat kualitas pelayanan (X) sama dengan nol (0).

2. Nilai sebesar 0,722 pada koefisien $X$ yaitu jika kualitas pelayanan $(X)$ naik sebesar 1 satuan unit skor, maka kepuasan pelanggan (Y) naik sebesar 0,722 dengan asumsi faktor lain (e) konstan.

\section{Pengaruh Kualitas Pelayanan terhadap Kepuasan Pelanggan pada Restoran dan Pemancingan Ajo Karawang Barat}

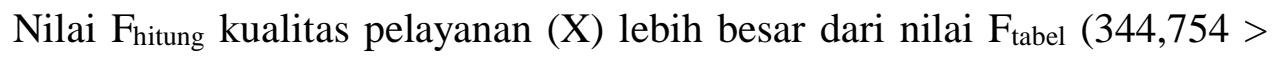
$3,89)$ atau tingkat signifikansi $\mathrm{F}$ lebih kecil dari nilai alpha $(0,000<0,05)$, dengan demikian bahwa variabel kualitas pelayanan $(\mathrm{X})$ berpengaruh signifikan terhadap variabel kepuasan pelanggan (Y). Nilai $t_{\text {hitung }}$ kualitas pelayanan $(\mathrm{X})$ lebih besar dari 
$\mathrm{t}_{\text {tabel }}(4,557>0,675)$ atau tingkat signifikansi $t_{\text {hitung }}$ lebih kecil dari nilai alpha $(0,000$ $<0,05)$, dengan demikian bahwa terjadi penolakan $\mathrm{H}_{0}$ atau penerimaan $\mathrm{H}_{a}$ yang berarti menunjukan adanya pengaruh variabel kualitas pelayanan (X) secara signifikan terhadap variabel kepuasan pelanggan (Y).

\section{KESIMPULAN}

Tingkat kualitas pelayanan restoran dan pemancingan Ajo - Karawang Barat berada tingkat cukup baik. Keadaan ini ditunjukan dari nilai rekapitulasi jawaban responden mengenai kualitas pelayanan. Tingkat kepuasan pelanggan pada restoran dan pemancingan Ajo - Karawang Barat berada pada tingkat cukup baik. Keadaan ini ditunjukan dari nilai rekapitulasi jawaban responden mengenai kepuasan pelanggan. Kualitas pelayanan berpengaruh signifikan terhadap kepuasan pelanggan. Keadaan ini ditunjukan dari nilai $F_{h i t u n g}$ dengan tingkat signifikan lebih kecil dari nilai alpha $(\alpha)$ atau juga ditunjukan dari nilai thitung dengan tingkat signifikan lebih kecil dari nilai alpha $(\alpha)$.

\section{DAFTAR PUSTAKA}

Dr. Ir Bob Foster, MM, 2008. Manajemen Ritel. Cetakan kesatu, Penerbit Alfabeta $\mathrm{Cv}$, Bandung.

Fandy Tjiptono, Gregorius Chandra, Dadi Adriana, 2007. Pemasaran Strategik. ANDY, Yogyakarta.

Fandy Tjiptono, 2004. Pemasaran Jasa. Edisi Ketiga. Bayumedia Publishing, Malang Jawa Timur.

Lupiyoadi, Rambat, 2001. Manajemen Pemasaran Jasa Teori dan Praktek, Edisi pertama, Yogyakarta : Andy Offset.

Philips Kotler, 1997. Manajemen Pemasaran, Edisi bahasan Indonesia Jilid 1. By Prentice-Hall, Inc. A Simon \& Schuster (asia) Pte. Ltd.

Philips Kotler, 2002. Manajemen Pemasaran, Edisi Mellenium Jilid 1. By Pearson Education asia Pte. Ltd dan PT. Prenhallindo, Jakarta.

Rambat Lupiyoadi, A. Hamdani, 2006. Manajemen Pemasaran Jasa. Edisi 2. Salemba Empat, Jakarta.

Siswoyo Haryono. 2004. Metode Penelitian Bisnis. Badan Penerbit MM UTP, Palembang. 
Siswoyo Haryono. 2007. Metode Penelitian Bisnis. Badan Penerbit MM UTP, Edisi Kedua, Palembang.

Siswoyo Haryono. 2007. Statistika Penelitian Manajemen. Program Pascasarjana Magister Manajemen, UTP Palembang.

Soelaiman Sukmalana. 2005. Evaluasi Kinerja. Program PPs UTP.

Steven Schauffer, Ph.D \& Tom Pinkerton, Ph.D. 2007. Building Loyal Customers. Prestasi Pustakakarya, Jakarta.

Sri Mulyono, 1998. Statistika Untuk Ekonomi Edisi Revisi. FEUI, Jakarta.

Stephen P. Robbins, 1996. Perilaku Organisasi Jilid Dua. PT. Prenhalindo, Jakarta.

Stoner, Freeman, dan Gilbert terjemahan Sindoro Alexander. 1996. Manajemen. PT Bhuana Ilmu Populer, Jakarta.

Sugiyono, 2002. Statistika untuk Penelitian. CV. Alfabeta, Bandung.

Sugiyono, 1999. Metode Bisnis. CV. Alfabeta, Bandung.

Tjiptono, Fandy \& Anastasia Diana, 2001. Total Quality Manajement (Edisi Revisi). Yogyakarta : Andy Offset. 